7. Landon H.C.R. Haydn: Chronicle and Works. 5 vols. London: Thames and Hudson, 1976-1980. Vol. I: Haydn: the Early Years 1732-1765 (1980). 656 p. [in English].

8. Landon H.C.R. Haydn: Chronicle and Works. 5 vols. Vol. Il: Haydn at Eszterháza 1766-1790 (1978). 800 p. [in English].

9. Landon H.C.R. (1955). The Symphonies of Joseph Haydn. London: Universal Edition \& Rockliff [in English].

10. Spitzer J., \& Zaslaw N. (2004). The birth of the orchestra. History of an institution, 1650-1815. Oxford - New York: Oxford University Press [in English].

11. Werke Joseph Haydn. (2006). München : G Henle [in German].

Стаття надійшла до редакції 25.08.2019 p.

УДК -781.033

\author{
Шевченко Лілія Михайлівна \\ кандидат пед.наук, доцент Одеської національної \\ музичної академії ім.А.В.Нежданової \\ ORCID 0000-0001-8602-9573 \\ lilia.my.forte@gmail.com
}

\title{
СУЧАСНА ПІАНІСТИЧНА КУЛЬТУРА І БЕТХОВЕНІАНСТВО - МОЦАРТІАНСТВО В НІЙ
}

Мета роботи - виявити характер взаємодії моцартіанських і бетховеніанських стильових традицій у фортепіанній грі в їх неоднозначній соприсутності і взаємодії в успадкування культурно-мистецьких напрацювань минулого століття. Методологічною основою роботи $є$ культурологічний підхід у мистецтвознавстві, представлений у тому числі школою Б.Асафьєва в Україні, початки якого зафіксовані французькою Ars nova кануну XIV століття й повернені в русло театрального мимезису Ж.-Ж.Руссо. Базисне місце займає метод жанрово-стильового порівняльного аналізу, герменевтичний, історико-описовий методи, що дозволяють у межах культури зафіксувати значеннєві паралелі становлення гуманітарної сфери й виразності мистецтва. . Наукова новизна роботи полягає в тім, що вперше у культурознавстві України висуваються стильові протиріччя піанізму в наслідування піаністичних шляхів моцартіанства і бетховеніанства як парадигмальний знак фортепіанної культури сучасності. Висновки. Виник і діє «гетерофонний» принцип у загальнокультурних позиціях фортепіанного музикування: бетховеніанська і моцартіанська складові стильової парадигматики піаністичної культури є явище всепланетарного значення. Її диз'юнктивний принцип, тобто якісно неврівноважене співвідношення мистецької угрунтованості бетховеніанства і широко охоплюючого позамистецький обрій моцартіанства, має певні унікальні, відзначені національною ментальною «хвилястістю» світосприйняття в Україні, яке народжує багатозначні, але продуктивні і цікаві пересічення вказаних типологій, які мають глибокі основи для подальшого розвитку музичного мислення.

Ключові слова: стильова диз'юнкція, піаністична парадигма, бетховеніанство, моцартіанство, фортенпіанне мистецтво, піаністична культура

Шевченко Лилия Михайловна, кандидат педагогических наук, доцент Одесской национальной музыкальной академии имени А.В.Неждановой

Современная пианистическая культура и бетховенианство - моцартианство в ней

Цель работы - проявить характер взаимодействия моцартианских и бетховенианских стилевых традиций в фортепьянной игре в их неоднозначном соприсутствовании и взаимодействии в наследовании культурнохудожественных наработок прошлого столетия. Методологической основой работы является культурологический подход в искусствоведении, представленный в том числе школой Б.Асафьєва в Украине, начала которой зафиксированы французской Ars nova кануна XIV столетия и повернуты в русло театрального мимезиса ж.Ж.Руссо. Базисное место занимает метод жанрово-стилевого сравнительного анализа, герменевтичний, историко-описательный методы, которые позволяют в пределах культуры зафиксировать смысловые параллели становления гуманитарной сферы и выразительности искусства. Научная новизна работы заключается в том, что впервые в культуроведении Украины выдвигаются стилевые противоречия пианизма в наследовании пианистических путей моцартианства и бетховенианства как парадигмальний знак фортепианной культуры современности. Выводы. Возник и действует «гетерофонный» принцип в общекультурных позициях фрортепианного музицирования: бетховенианская и моцартианская составляющая стилевой парадигматики пианистической культуры есть явление всепланетарного значения. Её дизъюнктивный принцип, т.е. качественно неуравновешенное соотношение художественной внедренности бетховенианства и широко охватывающего внехудожественнный горизонт моцартианства, имеет определенные уникальные, отмеченные национальной ментальной «хвилястістю» мировосприятие в Украине, которое рождает многозначные, но продуктивные и интересные пересечения указанных типологий, которые имеют глубокие основы для дальнейшего развития музыкального мышления.

Ключевые слова: стилевая дизъюнкция, пианистическая парадигма, бетховенианство, моцартианство, фортенпианне искусство, пианистическая культура

Shevchenko Lilia, Candidate of the Pedagogical Sciences, Assistant Professor Odesa National Music Academy named after A.V.Nezhdanova

The modern piano culture and features of Beethooven's and Mozart's styles within the one

The purpose of the article is to show the nature of the interaction to Mozart and Berthoven style tradition in the piano play of their ambiguous joint presence and interactions in inheritance cultural-artistic life lengths to the past

() Шевченко Л. М., 2019 
century. The methodology of the work is the culturology approach in science about art, presented including the school of B. Asafiev in Ukraine, begin which are fixed french Ars nova begin XIV century and are turned in riverbed theatrical mimesis of J.-J. Rousseau. The base place occupies the method of the genre-style benchmark analysis, hermeneutic, historian-descriptive methods, allowing within fix the semantic parallels of the formation of the humanitarian sphere and expressiveness of art. The scientific novelty of the work is concluded in that for the first time in science about culture to Ukraine are brought forth of the style contradiction of pianism in inheritance piano ways Mozart style type and Beethoven style type as paradigm sign of piano cultures to contemporaneity. Conclusions. Appeared and acts "heterophony" principle in general cultural position of piano play: Beethoven and Mozart forming of style paradigm to the piano culture, there is a phenomenon of universal planetary importances. Its disjunctive principle that is unbalanced qualitative correlation artistic entering of Beethoven character and broadly covering out-art horizon of Mozart character play has determined uniquely, noted national national "waviness" world-outlook in Ukraine, which gives birth ambiguous, but productive and exciting intersection specified typology, which have a sincere central to the further development of the music thinking. The disjunctive approach to the study of the stylistic paradigm of one or another century brings to the cultural perspective the knowledge of epochal styles, which are unknowable in their entirety in the art of science since it is not the artistic sphere that constitutes the source and the impetus for their existence. Moreover, even the styles, which are the expression of creative differentiation of thinking, do not always feed in their origins specifically in the creative sphere this is the reason for the long neglect in the second half of the nineteenth and twentieth centuries such artistic and, at the same time, all-culturally encompassing phenomena such as the Rococo, the Biedermeier, and the center of modernity on the eve of the twentieth century - symbolism. ano culture

Key words: style disjunction, piano paradigm, Beethoven character play, Mozart character play, piano art, pi-

Актуальність теми дослідження зумовлена сьогоденною потребою усвідомлення закономірностей виявлення сучасної культури піанізму, яка складає об'єктивно національний здобуток країн планети. Той феномен неодноразово ставав предметом вивчення вітчизняних і зарубіжних науковців такими є праці Д. Андросової, Д.Кемпера, Х.Хойслера, Н. Кашкадамової, Л.Корній, О.Маркової, Дж.Пейзана, А.Пютца, М.Степаненка, Л.Степанової, Е.Стрікленда, Х.Штегера, Б.Шеффера, Х.Шенкера, С.Яроцинського, ін., у тому числі це парадигматичні стильові виміри фортепіанної культури. Але спеціальне виділення стильових антитез піаністичної парадигми XX-XXI ст. в її охопленнні мистецьких і позамистецьких культурних виявлень фортепіанних розробок - так проблема не ставилася, що й спричинює своєчасність й затребуваність, наукову і мистецько-практичну, висунутого питання: моцартіанська і бетховенніанська складові в піаністичній парадигмі культурної сучасності.

Мета роботи - виявити характер взаємодії моцартіанських і бетховеніанських стильових традицій у фортепіанній грі в їх неоднозначній соприсутності і взаємодії в успадкування культурномистецьких напрацювань минулого століття.

Методологічною основою роботи є культурологічний підхід у мистецтвознавстві, представлений у тому числі школою Б.Асафьєва [2] в Україні [1; 8; 9, ін.], початки якого зафіксовані французькою Ars nova кануну XIV століття й повернені в русло театрального мимезису Ж.-Ж.Руссо. Базисне місце займає метод жанрово-стильового порівняльного аналізу, герменевтичний, історико-описовий методи, що дозволяють у межах зафіксувати значеннєві паралелі становлення гуманітарної сфери й виразності мистецтва. . Наукова новизна роботи полягає в тім, що вперше в музикознавстві України висуваються стильові протиріччя піанізму в наслідування піаністичних шляхів моцартіанства і бетховеніанства як парадигмальний знак фортепіанної культури сучасності.

Піаністичні вподобання, як вони склалися в «етажності» буття і мислення XX сторіччя, охоплюють не тільки світ мистецтва, але і культурні шари поза нього, популярну і мас-культурну сфери, які дали вагомий внесок у фортепіанні надбання XX сторіччя. Якщо бетховеніанство і моцартіанство в ієрархії усвідомлення першого як «прогресу», а другого як «консервативного» фрактора складало у вік романтизму здобуток мистецьких баталій, то у XX ст., попри «перевернення» цінностей «прогресу» i «актуальності», що саме по собі значиме, виходимо на усвідомлення мас-культурних здобутків, світіння яких маємо у рок-опері, мюзиклі і інших помежовних з «третім рядом» жанрах. В них віддзеркалена безпосередньо концепція фортепіано, що йшла повз художньо самодостатнє мистецтво, тобто подаючи культурно-загальний, але не мистецьки - цивілізаційний пласт.

Саме культурна функція фрортепіано - діяльність «таперів» у німому кіно, де не рояльна прооркестральна самозначущість (в окремих випадках і той тип фортепіанного «висловлення»), але клавірна моторність на підтвердження «життєвої реалії» втіленого на кіноплівці утримувала дотичний до мистецтва, але не мистецький у власному значенні тип фортепіанної участі у кіносеансі.

Верх такого «переплутування» загальнокультурних і мистецьки-цивілізаційних показників знаходимо в поданні культури фортепіанної гри - у заміщенні її цілком клавірами, чи то органу (включаючи естрадний електроорган), чи то піаноли в популярній сфері, яка продемонструвала тим самим «відлучення від фортепіанор», особливо що стосується його оркестрально-всеохоплюючого єства. Кінематограф, найваизначніший, поряд з архітектурою, вид мистецтва XX ст., у вигляді «великого німого» немало зазначив у загальномистецьких виявленнях, у тому числі це його буття «під тапера» (франц. tapeur, від фрранцузького taper, «стукати» [10, 653]), тобто в продовження манери гри фрортепіанного «білого джазу» типу рег-тайму, - чітко засвідчив «антирояльну» стратегію фрортепіанного подання і стверджуючи позахудожні межі клавірного моцартіанства XX cm. 
Так витонченість символістського фортепіанного салонного вираження виходила на «механіку бізнес-реклами», на розважально-спрощений вимір заявлення художніх здобутків. Не забуваємо, що саме символізм, поряд із салонністю, затвердив звернення художників до мистецтва реклами, відновив у Росії інтерес до примітивної лубочної продукції, взагалі висунув примітив як такий на положення суттєвого чинника відкрить мистецтва Таємниці.

У класика російського символізму О. Скрябіна, якого, за визнанням Г.Еймерта, слід вважати початком «світового авангарду» [31, 38], значить, поставати предтечею експресионізмy/неоекспресионізму XX століття, знаходимо визнання про розгорнутість пошуків композитором музики, що засвідчує «нетрагізм буття» [11]. Такий поворот думок автора «Містерії» оголює християнсько-православний, більше того, ісихастський грунт переконань композитора-піаніста, що має певні паралелі до брахманістських-індуістських і буддистських уявлень про мінімалізацію фрізичної присутності у енергійних виявленнях Екстатики. Звідси виходимо на визнання християнсько-містеріальної основи скрябінівської містеріальності, як це приведено на сторінках «Южного музыкального вестника» за 1916 р. з викладенням полеміки з М. Івановим, який відстоював суто християнське джерело Містерії [11, № 1-2 янв., с.3].

Так вимальовується християнсько-ісихастська стимуляція творчих відкрить Екстатики О.Скрябіна, показова для слов'янської школи як абсолютизації абстрактно-духовного виявлення безмежної Радості буття і подолання фрізичної обваженості образу. Паралелі цьому - у «Глаголичній месі» Л.Яначека, у Четвертій, із солюючим фортепіано симфонії К.Шимановського, у творах О.Мессіана та І.Вишнєградського, М.Обухова, що понесли у планетарний простір відкриття слов'янського дерзання Скрябіна, підтриманого в Україні і того, що має теоретичну паралель у розробках поляка Л.Роговського і «скіфських» творчих відкриттях С.Прокоф'єва, народженого в Україні.

Розвиваючи тезу про піаністику Скрябіна як угрунтованої на салонному стилі Мосвки і дотичної до традицій французького фрортепіанного мистецтва, Д.Андросова констатує щодо виразної суті піанізму творця «Поеми екстазу» з її «проісихастською» назвою:

«То був піанізм 'польотний', що використовував 'другу клавіатуру', тобто гру на піднятій кисті, що йде від староклавірної традиції мелізматичної гри. Але С. Михайлов справедливо вбачає в цих ознаках - національні традиції. А глибинний аспект цієї традиції - піднятий в працях Б. Яворскього, великого эетузіаста національних російських коренів фрортепіанної спадщини О. Скрябіна...» [1, 133].

Безпосередньо втілена у «польотному» піанізмі О.Скрябіна ідея «дематеріалізації буття» як переломлення «руського максималізму» трактування Віри (див.у авторитетному духовному виданні «История русской Святости»: «Ця жадоба космічного преображення - одна із найяскравіших рис руського релігійного духу» $[6,5]$

Але такого роду творча позиція О.Скрябіна може розглядатися як піаністично-екстремальна - i тут напрошується посилання на сучасника, правда, того, що набагато пережив творця «Поеми екстазу», на С.Рахманінова, «дзвонність» якого для багатьох втілювала «російську міць». Але таке бачення явно спрощує феномен С.Рахманінова - адже він був «шопеніанцем» за витоками не менш, ніж О.Скрябін, навчався піаністичній майстерності у того ж М.Звєрєва, який виховав Скрябіна. Щодо шопеніанства Рахманінова яскраво пише автор монографії, присвясеній Рахманінову, В.Брянцева, вказуючи на певні показові співвідношення в репертуарі піаніста, у тому числі у звертанні до композицій польського генія:

«Всього Рахманінов публічно зіграв більш ніж 400 фортепіанних творів п'ятидесяти з додатком композиторів.... В кількісному відношенні тут на першому місті стоять власні твори.... Майже стільки ж місця займає Шопен...» [4, 610].

Щодо сутності ліричного мислення С.Рахманінова в його композиторській і, особливо, виконавській іпостасях, слушно зауважено у книзі Д.Андросової:

«Об'єктивно лірика Рахманінова пронизувана тою славильністю, яка піднята над емоційнобутійними проявленнями. Особливо це наочно виявилося в його виконавській манері, в якій «суховато»-стримано (салонний штрих!) подаються відповідні фрагменти його музики. Найбільш наочно ті риси ліризму (курсив Л.Ш.) Рахманінова виявляється в його Концертах, в їх виконанні автором. І вказанні штрихи засвідчують про “незмагальну» природу жанрової трактовки творів (йдеться про жанр концерту - Л.Ш.)» [1, 263].

У книзі Д.Андросової приділена увага ліричній обраності антилістівського піанізму XX ст., уособлюваного в послідовному виявленні О.Скрябіним і Г.Гульдом, але який охоплює увесь обсяг тенденцій видатних митців від фортепіанної гри минулого століття, включаючи геній С.Рахманінова, С.Прокоф'єва, Б.Бартока, М.Аргеріх, М.Плетньова та ін. Щодо сутності цього моторно-клавірно представленого ліризму підкреслюємо його аллілуйно-славильну підоснову, віртуозний грунт в етимологічному значенні «доблесті», «героїки» вираження, яка надихала фігуративну вишуканість церковного гимноспіву і, відповідно, його інструментальних проєкцій в духовній музиці і у позацерковних зібраннях типу салонних аристократичних спілкувань заради наслідування «доброго пастирства» першохристиянської общинності [1, 190-192]

Дж.Пейзан, автор монографії, присвяченої величному піаністові XX сторіччя, відзначав і аргументував у наступних термінах ліризм Г.Гульда: 
«Його фрортепіанний стиль - тонкий, вишуканий, ритмічно динамічний, структурно визначений, настирливо контрапунктичний - був скоріш модерністським, ніж романтичним, і все ж залишається більш за все ліричним (курсив Л.Ш.) і глибоко виразним. Як інтерпретатор, однак, він був останнім романтиком... Його широкий, при цьому вкрай різноманітний репертуар коливається від вірджіналістів до нині живучих канадців. Це було видиме, помітне висвітлення раннєромантичної музики...» (перекл.українською автора [13, 34 ]).

Як би не тлумачив Дж.Пейзан той ліризм Г.Гульда, протиставляючи романтизмові як епохальному явищу і стилю-напрямку музичного мислення XIX сторіччя чи зближуючи з методом-підходом Гульда як піаніста-інтерпретатора, але суттєвим виступає розширене тлумачення ліризму як загально-художнього показника, який тримається на лінеарно-моторному (контрапунктичному у Гульда!) фрактурному виявленні. I тим самим ліризм постає у понадіндивідуальному показчику виразу, сягаючи мелодійно-гетерофронного обсягу музики XX сторіччя у цілому (за Е.Куртом [7]). А, як відомо, кожне епохальне виявлення концептується ідеями епохального ж етнічного лідерства за Х.Ріманом [14], що й надихнуло його учня, знаного Г.Адлера до узагальнення про лідерство російської школи у модерні ХХ століття [12, 901].

Але загальний підсумок мистецтва минулого століття вказує на впливовість східноєвропейських впливів на світовий музичний простір. Адже виняткова роль джазу й рок'у в маскультурних здобутках вказує на «ірландський ген» їх стильового стимулу, а, значить, на візантійський грунт їх національно-творчої позиції. І це безпосередньо визиває до життя у якості провідної позиції музики епохи постмодерну, тобто 1980-х - 1990-х років, грецьку школу, спадкоємицю Візантії, що представлена у другій половині XX століття геніями фрахового мистецтва - М.Теодорокісом, Я. Ксенакісом, Є. Вангелісом.

А в популярному, мас-культурному середовищі виділяється грек Д.Руссос, що в сценічному образі і в манері вокалізації демонстрував візантійський початок свого співу. І в цьому ж роді виділилася також ірландська школа в танцювальній і співацькій сферах, нарешті, висвітився феномен Валі Балканської, зразок фольклорно-духовного вираження якої стало знаком високого популярного стилю планети у посланні до космічних братів за розумом американської експедиції 2002 року. Справедливо відмічає дослідниця болгарського внеску у мистецтво минулого століття дослідниця Л.Нейчева:

«Болгарська музика в її національній специфіці вагома в міжнародних масштабах своєю причетністю до традицій греко-ірландського лідерства в популярній сфері сьогодення, в тому числі в області церковної музики. Адже актуальність співу за ісоном для сучасного Православ'я, що культивувався від початку Християнства в монастирях Афона і що існує в Україні та Росії і до нині в церковному мистецтві, - висвічує той фактор, що бурдоний-ісоний принцип фрактури є традиційним для болгарського фольклору та церковності. Відповідно, конфесійна затребуваність по відношенню до бурдоноісонового звучання на сучасному етапі «входить в резонанс» 3 споконвічно-болгарськими співочими навиками, що просувають сукупно національне мистецтво цього народу до музично-лідируючих позицій в стилістичному положенні сьогодення» [9, 4]. століття:

I вказана авторка слушно уточнює візантійський стимул успіхів болгарської школи минулого

«Болгарська музика історично найбільше наближена до візантійсько-грецьких витоків Християнського мистецтва, а через Кирило-Мефодієвську традицію - до устоїв Ірландсько-Галльського Православ'я, від чого вона стала досить помітною в 'греко-кельтській хвилі', що висвітилась в художній сорері в кінці XX - початку XXI ст.. у зв’язку з висуненням А. Пьяццолли та Вангеліса на провідні позиції стилістики професійної музики світу. В цьому випадку звертаємо увагу не тільки на композиторський вихід болгарських авторів, але й на активність музикознавства Болгарії в загальноєвропейському положенні, що сукупно визначило вагомий вклад цієї 'маленької країни' в світову культуру минулого століття» [там же].

Вказане просування на європейський Схід лідерствуючих шкіл європейського художньосамодостатнього мистецтва з виявленням клавірного ліризму фортепіанного виконавства у XX сторіччі завершується «вибуховою кульмінацією» даного процесу: вихід на світову арену європейської композиторської творчості представників китайської культурної генерації - в особах корейця Юн Ісанга і Тань Дуня.

I подібне ж здійснюється в мас-культурній сфері: вражаючий успіх старовинної аристократичної китайської опери куньцюй у США та Західній Європі у 2000-і роки. Відмітимо, що цей «прорив Сходу», вперше за все існування європейського художньо-самодостатнього музичного мистецтва, у професійній композиторській сфері був підготовлений виключними успіхами китайських піаністів від 1950х років, з блискучої перемоги Лю Шикуня на Першому Міжнародному конкурсі імені П.І.Чайковського у 1958 році аж до сьогоденних перемог Лан Лана, Лі Юнді, Юджи Вангі та багатьох інших. Показово, що вказані та інші китайські віртуози охоплюють можливості лістівської фрортепіанної оркестральності, але «значеннєвим ядром» їх репертуару виступає моцартівська-шопенівська-скрябінівська лінія піанізму, дотична до а-/антиоркестральної позиції Г.Гульда.

А щодо актуального для XX ст. перегляду спадщини Й.С.Баха в торактуванні ї̈ у моцартіанськи-клавірному поданні, то поряд із відкриттями Г.Гульда треба додати такі чисто піаністично- 
виконавські вирішення як експериментально-авангардистські прочитання Баха в редакції Б. Бартока, де лінеарний запис п'єс ДТК становить стилістичну паралель «полегшеним» необарочным установкам інтерпретації Г. Гульдом творів творця Пасіонів.

Головною думкою даного викладення $€$ уявлення про фортепіанну парадигматику, передусім, моцартіанського (антирояльного) спрямування XX i, значною мірою, XXI ст. як представительствуючої не тільки від мистецької сфрери, але від культурних обріїв взагалі, оскільки «антирояльний рух» охопив прикладну сферу, сфреру джазу, гру «таперів» у «великому німому». А в них не театральносимфонічне «наслідування життя» у загально-процесуальних вимірах, але «стукання» (taper = «стукати») заради вписування у життя як таке чи знаково-сакральне нагадування про позахудожні життєві цінності (орган у «Привиді опери» Л.Уеббера) й ін. - засвідчують актуально-сьогоденну затребуваність клавірності-піаністичності.

I в цьому напрямі спрацьовує паралелізм виявлення необароко у післявоєнних десятиріччях 1950-х - 1960-х, коли на тлі моди New Lac, чи то безпосередньо копіювавшої «понадвузенькі талії сукенок» в зовнішності Б.Бардо, Л.Торез, Л.Гурченко, чи то демонструвавших у міні-моді інфантильні втілення 1730-х, впевнено сходило до апогею рок-мистецтво, відновивши актуальне подання танцювальної продукції 1920-х років. А у фортепіанних виходах авангарду другої хвилі затверджувався «клавесинізм» П.Булеза, Л.Грабовського, фортепіанних опусів О.Мессіана, Е.Денисова, «Секвенцій» Л.Беріо та ін.

Дані піаністичні пошуки в напрямі клавесинності неорококо показові і в тому значенні, що віддзеркалюють вони установлення аристократії XVIII ст., які не ставили метою засередження на мистецтві як такому: салони - це духовні, політично-проповідницькі, «розважальні» у високому значення «шаріння душ» зібрання, але ніяк не зосередженні на театрально-життєнаслідуваній меті художності як такій. Пролонгації рококо у мистецтво Реставрації першої половини XIX ст., що зумовило стильово-світоглядне «забарвлення» піанізму «легкого» типу у салонному переломленні бідермайєра поза німецького культурного ареалу, виявили шар «тривіального» бідермайєра, «тривіальної» ж салонності, які демонстрували те мистецтво «без імен і шедеврів», яке надовго відвернуло від цих ланок культури шанувальників мистецтва як художнього надбання понад усе.

Але все ж бідермайєр і салон XIX ст., існуючи поряд з театралізованою ходою симфонізму і симфонізованного ж «рояльного» піанізму, все ж усвідомлювався у грі Дж.Фільда, Й.Гуммеля, Ф.Шопена, Дж.Россіні, ін.великих піаністів, «легкий» стиль гри яких відповідав релігійно-духовним початкам творення. I тим їх естетизм складав достойну паралель художньо втілюваному мистецтву симфонізованної фортепіанної гри, уособлювану Ф.Лістом, Ан.Рубінштейном, І.Альбенісом і багатьом іншим віртуозам пробетховеніанського типу. Цим підкреслюємо спільність художнього виміру «співіснування» салонного і симфронізованного фрілармонічного піанізму першої половини XIX, який був відкинутий у другій половині цього ж віку на користь торжества симфоонізму-оркестральності.

Звідти - висновок про кон'юнктивний принцип стильової двоскладової парадигми першої половини XIX століття, тоді як XX століття демонструє дещо протилежне. I це не тільки відмічена вище «оберненість» орієнтирів, коли гаслом фрортепіанного прогресу для XIX ст. був Бетховен, а моцартіанство засвідчувало «вірність аристократичним заповітам» (що схвально приймалося у часи Реставрації, а згодом люто відштовхувалося після демократичного завзяття революцій 1848-1849рp.). A у XX ст. все повернулося навпаки: бетховеніанство засвідчувало академічний грунт гри, а моцартіанство піаністичний модерн-авангард, втілюваний у світових вимірах виконавською творчістю О.Скрябіна і Г.Гульда.

Співвідношення моцартіанства-бетховеніанства наубло у XX ст. ще одної якості, неможливої у XIX ст.: воно вийшло за рубежі худолжньої сфери як такої і охопило загально-культурні простори. Моцартіанство як антирояльний прицнип клавірної гри - це і культура тапера (і на танцях, і в кіно), за якою стоять не художні, а компенсативно-естетичні вади різних верств населення, це і відмова від піаністичності як такої на користь електрооргану у рок-музиці (і відображуючої ці вибори рок-опери чи до опери наближеного мюзиклу). Але це і весь авангард, і певна (і впливова в професійній сфері) «серединна» стильова лінія неокласичного гатунку, а, через неї, актуальна корекція традиціоналізму і академічного бетховеніанства як такого.

Звідси - теза про диз'юнктивний принцип стильової двоскладової парадигми фортепіанної гри $X X$ cm., оскільки тут на «випадкових» началах співіснування існували (і існують) культурно різні шари ігрових вмінь: саме фортепіанне мистецтво - і його «перетворення» у прикладній сфері. Парадоксом виглядає дотичність саме моцартіанської лінії піанізму до «грубої прози» танцювальних зібрань і неуважного слухання «супровіду» під час демонстрації стрічки «великого німого». Але у вказаній парадоксальності, як вже вказано, є своя закономірність: мистецтво рококо, увага до якого випливає у XX сторіччі (як віку «молодіжного наступу»), було органічною часткою культурного буття, відсторонюючи театральне «наслідування життя».

Таким чином, ознаки диз'юнктивного подання стильової парадигми фрортепіанного мистецтва XX століття відзначені такими факторами:

культурною вписаністю стильової двоскладовості (бетховеніанство - моцартіанство - чи навпаки, моцартіанства - бетховеніанства) у культурний «розтин» минулого віку, де співіснували не у 
гармонічній рівновазі дві політичні системи-антагоністи (соціалізм - імперіалізм), усі мистецькі події жорстко підпали під диференціацію «мистецтво для нас - мистецтво для мас» (що перефразовано 3 висліву Д.Шостаковича - «музика для нас - музика для мас»), а у фрілософії у 1940-ві роки середини сторіччя Т.Адорно заявимв «двохфазову діалектику» у філософії, перекресливши тим самим «життєподібну» процесуальну трифазову розчленовість тези-антитези-синтезу (пор.із «формою-процесом» у класичній музиці за Б.Асаф'євим за формулою i:m:t);

- угрунтованість моцартіанських позицій фортепіанної гри у вимірах прекрасного, дотичного до уявлень до Краси духовної християнської музики Середньовіччя й Церковності в мистецтві взагалі, й одночасно охоплюючого, з убуванням рівня Краси аж до красивості побутових явлень, що й пороявилося у проникненні у прикладну сферу саме вказаної стильової позиції, тоді як бетховеніанство, невідривне від уявлення про піднесене, в якому краса поступається життєвим корекціям, що йдуть від надактивності духу, складає органічний прояв мистецького «наслідування життя» і виправдовується театралізованими акціями революцій і перебудов, але не зливаючись із життєвими акціями у власному значенні - останнє зумовило академізм бетховеніанства у фортепіанній творчості XX ст.;

- лінгвістичний виток самого терміну «диз'юнкція» відображує лінгвістично-семіотичний нахил світоглядних спрямувань мислення XX сторіччя у цілому, названого віком Науково-технічної революції і віком Психології підсвідомого, що втілює нестиковані реально сфери наукового раціоналістичного знання і непізнаного психологічного поля позараціонального призначення; усвідомлення культурної вписаності музично-піаністичних надбань у світовий простір планетарних людських стосунків $є$ продовженням на базі звукових достоїнств найакадемічнішого з інструментів, фортепіано, що претендував на найширше охоплення інструменталізму як «замінник оркестру», - пізнання соціально-психологічної сутності музики і мистецтва у цілому.

Диз'юнктивний підхід у вивченні стильової парадигми того чи іншого століття виводить на культурологічний ракурс пізнання епохальних стилів, які непізнаванні в повноті своїй у мистецтвознавстві, оскільки зовсім не художня сфрера складає виток і стимул їх існування. Більше того, навіть стилінапрямки, що є вираженням художньої диференціації мислення, не завжди у своїх витоках живляться спеціально мистецькою сферою - саме в цьому причина довгого ігнорування у другій половині XIX i y XX ст. таких мистецьких й одночасно всекультурно охоплюючих явищ як рококо, бідермайєр і осередок модерну в канун XX ст. - символізм.

Зникнення художніх напрямків в музичній творчості на рівні постмодерну-поставангарду, тобто на рівні «неосимволізму» за О.Марковою [8, 99-134] «зворотним ходом» висвічує позахудожні обрії символізму, класику якого в свій час А.Бєлий так і визначив: «символізм як світорозуміння» [3]. Позамистецтвознавчий термін «диз'юнкція», введений у даній роботі, що має фрілософські і лінгвістичні корені свого функціювання у науковому середовищі загалом, орієнтує на міждисциплінарний культурознавчий підхід до явища фортепіанного виконавства, в якому мистецтвознавчий вимір через буття «третьорядового» мистецтва джазу, через прикладну позамистецьку творчість тапера, нарешті, через реалії фрортепіанного «антирояльного» модерну принципово не охоплює існуючі різноманіття звуковиявлюваного сенсу.

Висновки. Виник і діє «гетерофонний» принцип у загальнокультурних позиціях фортепіанного музикування: бетховеніанська і моцартіанська складові стильової парадигматики піаністичної культури $€$ явище всепланетарного значення. Ї̈̈ диз'юнктивний принцип, тобто якісно неврівноважене співвідношення мистецької угрунтованості бетховеніанства і широко охоплюючого позамистецький обрій моцартіанства, має певні унікальні, відзначені національною ментальною «хвилястістю» світосприйняття в Україні, яке народжує багатозначні, але продуктивні і цікаві пересічення вказаних типологій, які мають глибокі основи для подальшого розвитку музичного мислення.

\section{תimepamypa}

1. Андросова Д.В. Символизм и поликлавирность в фортепианном исполнительстве XX в. Монография. - Одесса: Астропринт, 2014. 400 с.

2. Асафьев Б. Музыкальная форма как процесс. Москва-Ленинград, Музыка, 1971. 379 с.

3. Белый А. Символизм как миропонимание. Москва: Республика, 1994. 336с.

4. Брянцева В. С.В. Рахманинов. Москва, Советский композитор, 1976. 645 с.

5. Гойови Д. Е. Голышев и дада-сериализм.//Трансформація музичної освіти: культура та сучасність. Одеса, 1998. С. 96-101.

6. История русской Святости. По благословению Высокопреосвященнейшего Амвросия, архиепископа Ивановского и Кинешемского. - Москва: Молодая гвардия/Синтагма, 2001. 544 с.

7. Курт Э. Основы линеарного контрапункта. Мелодическая полифония И.С. Баха. Москва: Гос.муз.издат., 1931. 304 с.

8. Маркова Е. Проблемы музыкальной культурологии. Одесса, Астропринт, 2012. 164 с.

9. Нейчева Л.В. Болгарское музыкальное искусство как национально-стилевая парадигма в культуре XX - начала XXI веков. Канд.дисс., 17.00.03. ОНМА имени А.В.Неждановой. Одесса, 2016. 180 с.

10. Словник іншомовних слів. Ред. О. Мельничук. Київ: Голов.ред.Україн.Радян.енциклопедії, 1977. 776 с.

11. Южный музыкальный вестник, 1915, 1916. №№ 8-9; № 1-2. С.3-5; с.3.

12. Adler G. Handbuch der Musikgeschichte. Frankfurt a.M., Verlag-Anstalt, 1924. 